\title{
Modeling Air Travelers' Experience Based on Service Quality Stages Related to Airline and Airports
}

\author{
Claudia Munoz ${ }^{1,2}$, Henry Laniado ${ }^{3}$ \& Jorge Córdoba ${ }^{1}$ \\ ${ }^{1}$ Department of Civil Engineering, Universidad Nacional de Colombia, Medellín, Colombia \\ ${ }^{2}$ Environmental School, Universidad de Antioquia, Medellín, Colombia \\ ${ }^{3}$ Department of Mathematical Sciences, Universidad EAFIT, Medellín, Colombia \\ Correspondence: Claudia Munoz, Department of Civil Engineering, Universidad Nacional de Colombia, Medellín, \\ Cra. 80 No 65-223, Building M1, Office 211, Colombia. E-mail: chmunozh@unal.edu.co
}

Received: September 16, 2019

Accepted: October 6, $2019 \quad$ Online Published: October 12, 2019

doi:10.5539/mas.v13n11p37

URL: https://doi.org/10.5539/mas.v13n11p37

\begin{abstract}
This paper proposes a new scale for assessing traveler experience in air travel. Here, passenger experience is measured through travelers' perception of service quality, considering it as a chain of services. The new scale is called air travel service quality (ATSQ). It considers three service quality stages: departure airport service, airline service, and arrival airport service. This paper applies the ATRS scale to examine service quality in domestic travels in a Colombian context. Given that traveler's experience plays a crucial role in determining passenger's satisfaction, a structural equation model (SEM) was applied to examine the relationship between service quality stages, customer satisfaction, and behavioral intentions. Adding the passengers' perception of the arrival airport to the integrated service quality measurement is considering one of the main contributions of this study. The finding of this research confirmed that all three stages of air travel service have a significant, positive effect on passenger satisfaction. The scale found in this research should provide useful information for developing effective operational and marketing strategies for the air travel market. In this way, airports and airlines could better understand how traveler's perception of service quality may affect each choice related to which departure airport, airline, and arrival airport combination to choose from.
\end{abstract}

Keywords: airline, departure airport, arrival airport, integrated service quality, traveler's satisfaction

\section{Introduction}

Air transportation has been one of the fastest-growing modes of transportation in recent years (Kuljanin, Paskota, \& Kalić, 2018). Over the last two decades, the Colombian air transportation market has expanded considerably due to a high passenger growth rate (Díaz \& Pulido, 2019). It had grown from 10.7 million passengers in 2000 to 37.8 million passengers in 2018. This study focuses on the assessment of findings from the Colombian domestic air travel sector. According to Kirk, Harrison, Popovic, \& Kraal (2014), one of the strategies taken by the air transportation industry to increase profits has been to focus on the traveler's experience. Therefore, air carriers and airports have focused their attention on service quality and traveler satisfaction. To assess their performance, airline, and airport marketing managers have tried to evaluate air traveler experience. In the air travel sector, passenger's experience has been examined independently in airline and airport services. Airlines have measured air travel experience through travelers' perceptions of travel service quality based on airlines attributes (e.g. airline tangibles, in-flight service, employees, comfort, empathy, airline image, etc) (Kim \& Lee, 2011; Khuong \& Uyen, 2014; Saadat et al., 2018; Chen et al., 2019). In addition to travel experience assessment, air carriers have identified the importance of airline service quality on travelers' satisfaction and how travelers' satisfaction leads to their loyalty (Suki, 2014; Gures, Arslan \& Yucel Tun, 2014; Hussain et al., 2014; Park, 2019). On the other hand, studies on airport service quality have identified several travel experience factors related to security, servicescape, comfort, shopping, dining options, luggage policies, and facilities (Fodness \& Murray, 2007; Jeon \& Kim, 2012; George et al., 2013; Lee \& Yu, 2018). Besides, some researchers have suggested that airport service quality perception is a good predictor of airport passengers' satisfaction. (Ming-kei \& Yui-Yip, 2016; Prentice \& Kadan, 2019).

However, traveler's experience in air travel is a chain of services in which service quality perceptions can vary 
between different service delivery stages. Therefore, passengers' air travel experience is made up of three elements: departure airport service, airline service and arrival airport service. It is essential not only to understand how travelers assess the integrated service process but also to identify dimensions to measure integrated service quality in the air transportation industry.

Despite service stages have been measured separately, some studies have tried to evaluate air traveler's experience by considering two stages of service quality: departure terminal tangibles and air carrier elements (Suki, 2014; Kos Koklic et al., 2017; Farooq et al., 2018; Shoaib et al., 2018). Their findings showed the significant role of the airline and departure airport and how they affect a travel experience.

In this paper, we extend the understanding of traveler's experience in a travel by exploring the service process in their three stages: departure airport service, airline service, and arrival airport service. This study may fill the conceptual void existing in the air travel sector, by offering an integrated service quality measurement. This research finds a traveler's satisfaction model for air travel that has been developed by testing the effect of the three service stages on traveler's satisfaction and how it leads to loyalty. The satisfaction model also helps airlines and airports to understand air traveler's experiences and how their service quality perceptions may influence a future decision. It helps to suggest which departure airport/airline/arrival airport combination choose from.

This research contributes to the air travel experience literature in three aspects: first, by adding the traveler's perception of arrival airport to the integral service quality measurement. Second, by developing an assessment tool for evaluating traveler's experience in air travel, called here air travel service quality (ATSQ) instrument. Finally, by investigating the relationship between service quality in its different service stages and satisfaction, as well as the effect of traveler's satisfaction on future intention. Within this general framework, the present paper is, to the best of our knowledge, the first in presenting results from a Colombian context in which domestic travel experiences are assessed by the ATSQ scale.

The paper is organized as follows: Section 2 contains a brief literature review on service quality and traveler satisfaction. The hypotheses are included in Section 3. Section 4 explains the research methodology, data and variables. Our results are outlined in Section 5 and discussed in Section 6. The last section presents the conclusions of this research.

\section{Literature Review}

\subsection{Service Quality and Travelers Satisfaction}

In the air transportation industry, airlines and airports enjoy high revenues when traveler satisfaction increases because when travelers are satisfied, they are more likely to repeat their purchase. Airports and airlines recognize the necessity of studying traveler's satisfaction and identifying service quality indicators for improving the travel experience (Bogicevic, Yang, Bilgihan, \& Bujisic, 2013). Some studies of airlines and the airport industry have found a significant relationship between perceived service quality and passengers' satisfaction (Park, 2010; Hussain, Al Nasser \& Hussain, 2014; Al-Refaie et al., 2014; Prentice \& Kadan, 2019). Therefore, in the air transportation market, traveler's satisfaction plays an essential role in assessing service quality and its influence on loyalty (Park, Robertson \& Wu, 2005).

Different instruments have been developed to assess service quality. Parasuraman et al. (1988) proposed a model to measure service quality that included five dimensions known as tangibles, reliability, responsiveness, assurance, and empathy. The instrument was called the SERVQUAL scale. It has been widely applied by the air transportation industry and it has been a useful scale to compare customer's expectation with customer perception. See, for instance, Huang (2009); David Mc. A (2013); Mahmud et al. (2013); Elkhani, Soltani \& Jamshidi (2014); Chen et al. (2019). However, Cronin \& Taylor (1992) have questioned the well-known SERVQUAL scale on both theoretical and operational grounds because it compares customers' expectations with customers' perceptions of the services received.

Cronin \& Taylor (1992) instead developed the SERVPERF scale, which measures service quality based on customer's perceptions. Cronin \& Taylor (1994) found that the SERVPERF instrument explains more of the overall variance in the measure of service quality than the SERVQUAL scale. SERVPERF has proven to be a better scale for measuring service quality in the air transportation industry (Cunningham, Young \& Lee, 2004; Abdullah, Jan, Hazilah \& Manaf, 2012; Leong, Hew, Lee \& Ooi, 2015). However, some scholars have criticized those scales because they are quite generic and do not consider specific attributes of air transportation service quality. According to Cunningham, Young \& Lee (2004), a service quality scale should be assessed concerning a particular industry. Therefore, some scholars have proposed models with service quality dimensions related to 
airlines or the airport industry. However, service quality related to travel experience may vary at the different stages in the service process. Thus, in this research, service quality perception is broken down into three stages: departure airport service, airline service, and arrival airport service.

\subsection{Airline Service Quality}

Several studies have proposed models with dimensions of service quality that are related to the airline industry. For example, the models presented by Park et al. (2005) and Park et al. (2006) used factor analysis to identify three dimensionsreliability and customer service, convenience and accessibility, and in-flight serviceand then examined how each dimension affected traveler's satisfaction. Similarly, Gursoy et al. (2005) looked at on-time performance, mishandled baggage, involuntary denied boarding and handling of customer complaints as the dimensions for measuring service quality, whereas Babbar \& Koufteros (2008) revised four aspects of service quality, namely individual attention, helpfulness, courtesy, and promptness. Chen (2008) also assessed airline service quality, by using four dimensions, namely employees/facilities, product, transaction and, reliability.

Emphasizing the importance of in-flight meal service quality, An \& Noh (2009) based their model on SERVQUAL scale and proposed three new dimensions related to in-flight meal service, food quality, alcoholic beverage quality, and non-alcoholic beverage quality. By using factor analysis, Namukasa (2013) extracted three dimensions of airline service quality that contain eight attributes, including pre-flight service quality (reliability, responsiveness and discounts), in-flight service quality (tangible, courtesy and language skills), and post-flight service quality (frequent flyer programs and timeliness).

Regarding traveler's satisfaction antecedents and traveler's satisfaction consequences, Kos Koklic et al. (2017) found that airline tangibles and quality of personnel are a significant satisfaction antecedent, as well as intention to repurchase and intention to recommend are satisfaction consequences. Satisfaction antecedents were also examined by Saadat et al. (2018), who based the discussion on five service quality statements (service provided by flight attendants, tangible features, food service, online service, and ground staff). Their research demonstrated that only foodservice and ground staff have a significant impact on traveler's satisfaction.

\subsection{Airport Service Quality}

Some studies have addressed service quality issues only in the airport industry. George et al. (2013) used factor analysis and developed an airport service quality model called ASQual. They extracted 11 dimensions related to physical layouts, aesthetics, employee, eateries, shopping, transit support, information, security, customs, and passport control, baggage, business facilities, and miscellaneous. Bezerra \& Gomes (2015) also developed an airport service quality (ASQ) instrument. Bezerra \& Gomes' instrument was based on exploratory factor analysis and six dimensions were extracted (check-in, security, convenience, ambience, basic facilities, mobility, and prices). They also assessed the relationship between terminal service quality and overall satisfaction.

\subsection{Service Quality Interaction}

Bezerra \& Gomes (2015) suggested that future works should be focused on integrated service quality, by including dimensions related to airline and airport service quality because they share a significant area of overlap. Airports act as the first and last contact point for air travelers, and Kirk et al. (2014) found that negative airport experience can influence future travel plans. Ekiz, Hussain, \& Bavik (2006) tried to integrate service quality in two stages and developed a new instrument called AIRQUAL scale. This instrument measures airline service quality perception, by including a dimension related to the departure airport. AIRQUAL identified five dimensions of service quality: airline tangibles, terminal tangibles, personnel, empathy, and image. AIRQUAL scale has been widely applied to national and international travels (Nadiri et al., 2008; Suki, 2014; Ali, Lal Dey \& Filieri, 2015; Alotaibi, 2015; Mohamed \& Rani, 2016; Farooq et al., 2018).

Despite AIRQUAL applications in the air transportation industry, it might not be suitable for measuring overall traveler's experience through travel service quality measurement due to the different features of service quality related to the airline, departure airport, and arrival airport. This research attempts to extend previous works by incorporating traveler's experience with arrival airport into the perceived service quality measurement of the air travel.

Based on the foundations laid out above, the current study proposes a conceptual model shown in Figure 1. The underlying premise is that travelerspassengers' satisfaction with air travel is positively influenced by air travel service quality related to the departure airport, airline, and arrival airport. 


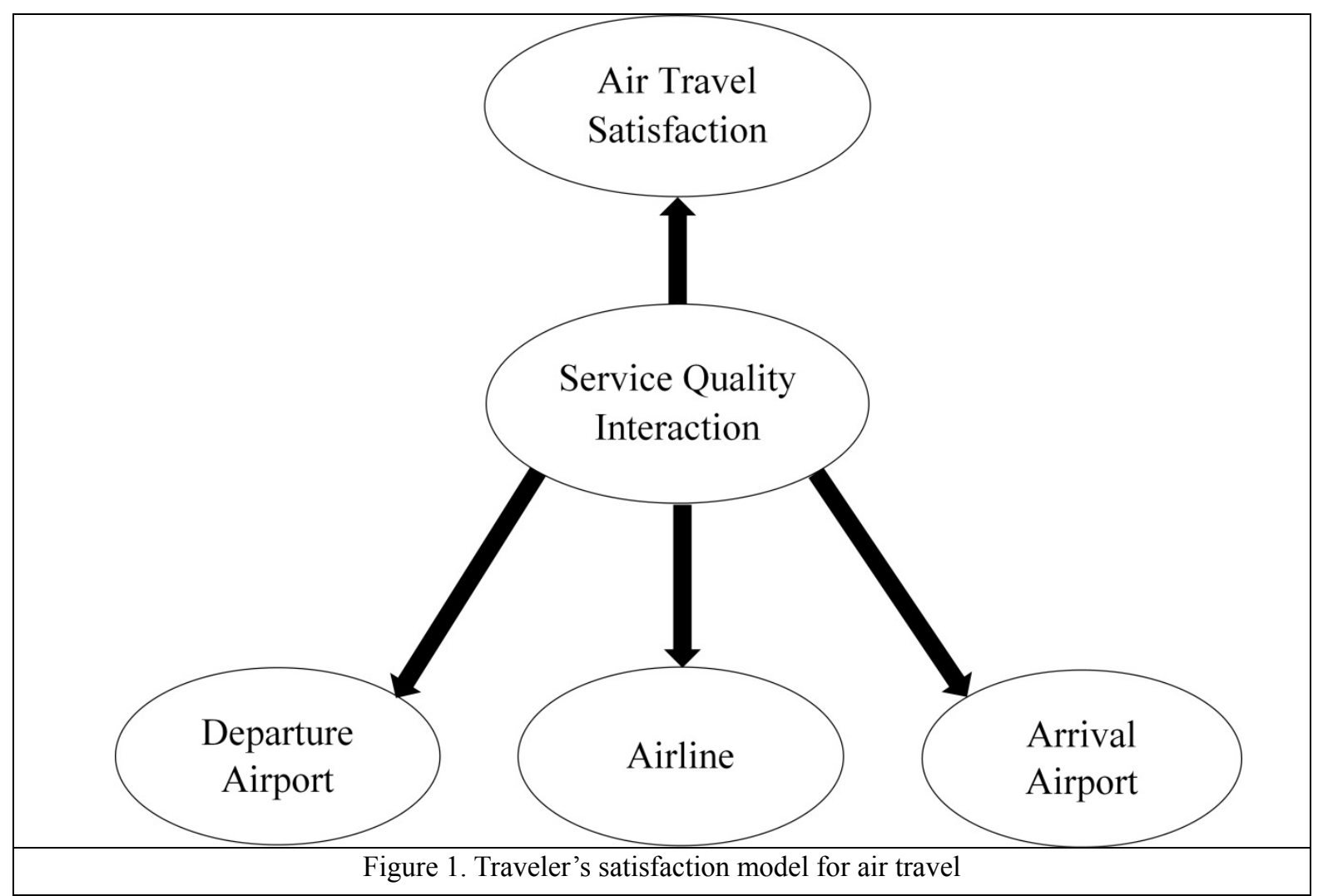

\section{Hypotheses that Explain Traveler's Satisfaction}

This study proposes a new instrument that measures air traveler's experience through passenger's perceptions of service quality of their recent air travel. This measurement instrument has been named ATSQ. The proposed theoretical model consists of dimensions related to the departure airport, airline, and arrival airport.

\subsection{Hypotheses Related to Airline}

According to Aksoy, Atilgan \& Akinci (2003), airlines are interested in understanding passenger's needs and their service perception to deliver better services. Hence, the delivery of high service quality has become an important requirement for airlines because of a competitive market. Kim \& Lee (2011) and Leong et al. (2015) found that perceived quality related to airline tangibles could play a fundamental role in traveler's satisfaction. For instance, Parasuraman et al. (1988) linked tangible dimensions with the appearance of physical assets, equipment, and communication materials. On the other hand, Khuong \& Uyen (2014) associated the tangibles factor with in-flight facilities and the appearance of staff and cabin crew. Thus, based on previous research, the airline tangibles dimension contains issues related to the interiority of an aircraft, such as the cleanliness of airplane toilets and the plane seats, quality of the air conditioning, and the comfort level of the plane seats, among others. Therefore, the hypothesis for the airline tangibles dimension is that airline tangibles have a positive impact on traveler's satisfaction.

H1: Perceived quality related to airline tangibles will have a significant positive effect on traveler's satisfaction.

Additionally, it has been found that even airline employees have a significant effect on customer service because travelers require a high degree of personalization. Therefore, traveler's perceptions of employees' performance can play a critical role in their assessment of service quality (See, for instance, Aburoub, Hersh \& Aladwan (2011). According to Chen (2008) and Kos Koklic et al. (2017)), the dimension related to employees highlights the importance of employees' attitudes, which includes their ability and willingness to help, to serve customers, and to create traveler's confidence. In this study, the staff dimension was designed to assess airline employees. Thus, the issues included in this dimension deal with employees' overall attitude, knowledge, and experience. Hence, it is hypothesized that:

H2: Perceived quality related to airline staff will have a significant positive effect on traveler's satisfaction.

Based on Parasuraman et al. (1988), empathy is defined as individualized attention that an air carrier provides to 
its customers. Nadiri et al. (2008); Suki (2014); Ali et al. (2015); Mohamed \& Rani (2016) and Farooq et al. (2018) found that airline empathy has a significant relationship with traveler's satisfaction. The present study also proposes an airline empathy dimension as part of the ATSQ instrument. This dimension has shown to play an essential role in creating a satisfactory traveler's experience. It includes questions related to the availability of transportation between the city and the airport, compensation schemes in case of loss or accidents, care paid to passenger's luggage and availability of health personnel during the flights. Accordingly, this study hypothesized that:

H3: Perceived airline empathy will have a significant positive effect on traveler's satisfaction.

\subsection{Hypothesis Related to the Departure Airport}

Considering the growing amount of air traffic worldwide, airport managers are interested in measuring, analyzing and extracting relevant information regarding traveler's perceptions of airport service quality (Bezerra \& Gomes, 2015). The departure airport is one of the key aspects of passenger transfer from the landside area to the airside area. Studies by Nadiri et al. (2008); Jeon \& Ki (2012); Al-Refaie, Bata, Eteiwi \& Jalham (2014); Ali et al. (2015); Mohamed \& Rani (2016) and Farooq et al. (2018) included in their research a dimension related to terminal tangibles and they found that departure terminal tangibles influence traveler's satisfaction. Eboli \& Mazzulla (2009) suggested that airport service quality should be measured by using the services related to the departing airport and arrival airport. Therefore, in this paper, service quality related to air travel experience is assessed, by using the departure airport dimension, airline dimensions and arrival airport dimension. The departure airport dimension is focused on attributes related to the departure airport, which includes questions on the cleanliness of the airport, the availability of shops in the airport tangibles, the availabity of parking spaces at the airport, the size of the airport, the airport's air-conditioning, and its security control systems, among others. Based on previous literature, the following can be hypothesized:

H4: Perceived quality related to the departure airport will have a significant positive effect on traveler's satisfaction.

\subsection{Hypothesis Related to the Arrival Airport}

The arrival airport is where passengers finish their journey and it is the first point of contact for passengers when they arrive at their destination. Passengers use different facilities and services that give them a final perception of service quality for their travel. Hence, the airport service quality plays a crucial role in traveler's satisfaction. Park (2019) argued that in addition to overall traveler's satisfaction, the service processes related to the departure airport and arrival airport need investigation. While some previous research has assessed travel experience through airline service and departure airport service, this research suggests understanding the travel experience also, by using arrival airport experience. Hence, the inclusion in this study of a new dimension related to the arrival airport. The measurement of the arrival airport dimension includes several elements, by including the comfort of the baggage claim area, the availability of trolleys in arrival airport, the size of the arrival airport and the cleanliness of the airport, among others. Taking the above into account, the following hypothesis on arrival airport perception and its impact on traveler's satisfaction can be formulated:

H5: Perceived quality related to the arrival airport will have a significant positive effect on traveler's satisfaction.

\subsection{Hypothesis Related to Loyalty}

According to the literature, traveler's satisfaction is an important drive of loyalty (Gures et al., 2014; Hussain et al., 2014; Leong et al., 2015; Park, 2019). Loyalty is often characterized by repurchase intentions, as well as word-of-mouth (WOM) communications. Cronin \& Taylor (1992) found that customer's satisfaction is a direct predictor of repurchase and WOW intentions. Additionally, Nadiri et al. (2008), Kim \& Lee (2011), Suki (2014) and Kos Koklic et al. (2017) found that a higher traveler's satisfaction level leads to higher loyalty. Loyalty is used as a dependent variable in the present study. Here, loyalty is defined as the degree to which a traveler recommends, and expresses a preference for, future use of a particular airline from a specific departure airport to a givenarrival airport. Therefore, the following hypothesis is put forward:

H6: Traveler's satisfaction will have a significant positive effect on brand loyalty.

\section{Methodology and Data}

\subsection{Case Study}

This paper examines the domestic air travel experience in Colombia. Several airport and airline were assessed by respondents. Figure 2 shows the geographical locations of the main airports included in the travelers assessment. 
Furthermore, Table 1 reports the airport characteristics and highlights airport importance according to passengers' traffic and aircraft movements in 2018.

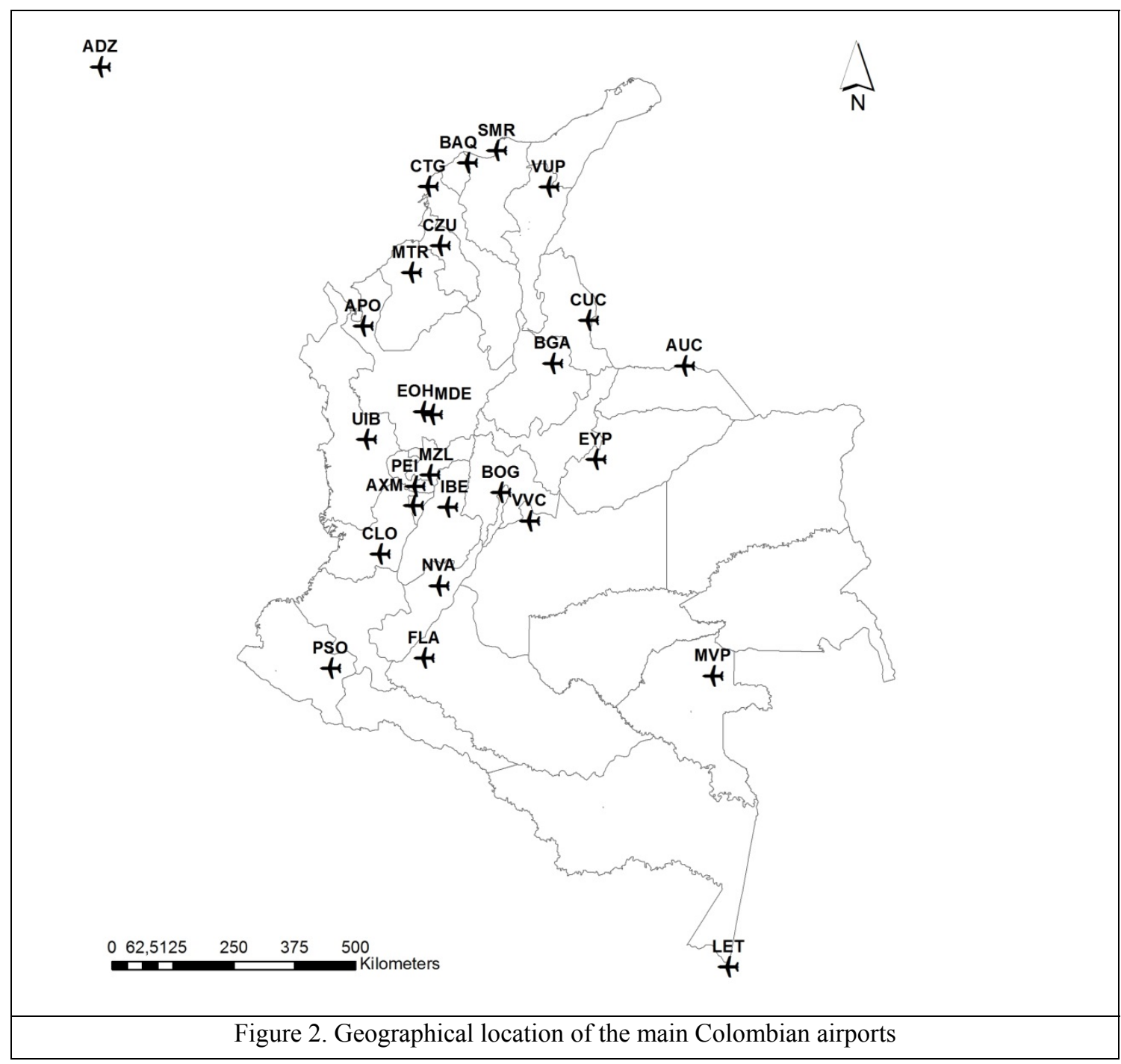

Table 1 shows that El Dorado (BOG) airport has the highest passenger's traffic and aircraft movements in Colombia, following by José María Córdova (MDE) airport, which represent $47.21 \%$ and $11.60 \%$, respectively of overall passenger traffic. Table 1 also establishes that BOG is easily the busiest airport, capturing just a little less than half the total number of passengers. Additionally, a large number of domestic routes are offered from BOG and MDE airports. The flight services are provided mainly by three airlines, two traditional airlines (Avianca and Latam) and a low-cost air carrier (Viva Air). 
Table 1. Characteristics of the airports

\begin{tabular}{|c|c|c|c|c|c|}
\hline Airport's name & $\begin{array}{c}\text { Code } \\
\text { (IATA) }\end{array}$ & Location & Status* & $\begin{array}{c}\text { Passenger } \\
\text { traffic }\end{array}$ & $\begin{array}{c}\text { Aircraft } \\
\text { movements }\end{array}$ \\
\hline El Dorado & BOG & Bogotá & I & $32,716,468$ & 333,433 \\
\hline José María Córdova & MDE & Rionegro & I & $8,036,411$ & 80,129 \\
\hline Rafael Núñez & CTG & Cartagena & I & $5,405,362$ & 54,036 \\
\hline Alfonso Bonilla Aragón & CLO & Cali & $\mathrm{I}$ & $4,870,311$ & 82,531 \\
\hline Ernesto Cortissoz & BAQ & Barranquilla & I & $2,582,290$ & 49,462 \\
\hline Gustavo Rojas Pinilla & $\mathrm{ADZ}$ & San Andrés & I & $2,188,527$ & 20,924 \\
\hline Simón Bolívar & SMR & Santa Marta & I & $1,998,099$ & 21,104 \\
\hline Matecaña & PEI & Pereira & I & $1,794,603$ & 29,148 \\
\hline Palonegro & BGA & Bucaramanga & I & $1,623,405$ & 34,814 \\
\hline Olaya Herrera & $\mathrm{EOH}$ & Medellín & $\mathrm{D}$ & $1,158,701$ & 76,091 \\
\hline Los Garzones & MTR & Montería & $\mathrm{D}$ & 931,449 & 24,921 \\
\hline Camilo Daza & CUC & Cucuta & I & 924,989 & 17,482 \\
\hline Alfonso López Pumarejo & VUP & Valledupar & $\mathrm{D}$ & 398,063 & 7,685 \\
\hline El Edén & AXM & Armenia & I & 396,110 & 20,783 \\
\hline El Caraño & UIB & Quibdó & $\mathrm{D}$ & 366,517 & 21,138 \\
\hline El Alcaraván & EYP & Yopal & $\mathrm{D}$ & 329,855 & 22,182 \\
\hline Antonio Nariño & PSO & Pasto & $\mathrm{D}$ & 326,634 & 5,849 \\
\hline Benito Salas & NVA & Neiva & $\mathrm{D}$ & 273,620 & 17,726 \\
\hline Alfredo Vásquez Cobo & LET & Leticia & I & 270,598 & 4,954 \\
\hline La Nubia & MZL & Manizales & $\mathrm{D}$ & 223,053 & 7,806 \\
\hline Antonio Roldán Betancourt & APO & Carepa & $\mathrm{D}$ & 206,696 & 21,451 \\
\hline Vanguardia & VVC & Villavicencio & $\mathrm{D}$ & 194,028 & 64,252 \\
\hline Perales & IBE & Ibagué & $\mathrm{D}$ & 129,804 & 21,759 \\
\hline Santiago Pérez & AUC & Arauca & $\mathrm{D}$ & 120,215 & 7,476 \\
\hline Gustavo Artunduaga & FLA & Florencia & $\mathrm{D}$ & 112,545 & 5,314 \\
\hline Las Brujas & $\mathrm{CZU}$ & Corozal & $\mathrm{D}$ & 96,211 & 4,924 \\
\hline Fabio Alberto León Bentley & MVP & Mitú & $\mathrm{D}$ & 51,942 & 14,480 \\
\hline
\end{tabular}

Source: (Aerocivil, 2019)

\subsection{Questionnaire Development}

The objective of this study is to measure air traveler's experience through service quality perception, by focusing on the Colombian domestic flights. To achieve this objective, the target population for this study was defined as all passengers having flown during the last month. Firstly, a pilot test was carried out with 30 passengers to assess the survey in terms of clarity, wording, and relevance. Finally, an online survey was conducted in order to test the proposed conceptual model. This study adopted a non-probability sampling approach. Initially, the questionnaire identified qualified respondents, i.e., passengers, who met the criterion of having had air travel experience during the last month. Then, they were invited to participate in the survey.

It is worth pointing out that the survey design was based on a literature review and specific features of service quality in domestic flights. Based on a margin of error of 0.05 for sample size and a $95 \%$ confidence level, a total of 330 questionnaires were distributed to passengers in 2017.

The survey questions were based on air traveler's service quality perceptions. The questionnaire was divided into five sections. The first and second sections contained demographic and the latest travel information, respectively. 
Third survey component had questions about service quality perception; some questions were based on the AIRQUAL scale (Ekiz, Hussain \& Bavik, 2006). The new scale proposed in this study, ATSQ, was made up of six items for airline tangibles, 14 items for departure airport tangibles, 14 items for arrival airport tangibles, eight items for airline staff and five items for airline empathy. The fourth section focused on the eight items of satisfaction measurement. Finally, the last section referred to four items of loyalty. The items were measured on a seven-point scale from 1 (extremely disagree) to 7 (extremely agree).

In terms of socioeconomic characteristics, gender representation within the sample was relatively balanced with $56 \%$ male and $44 \%$ female. Most of the survey participants (59\%) were aged between 18 and 40 years. Regarding their employment status, $75.5 \%$ of the sample was company employees. Concerning passenger's experiences, more than half of them had flown with the Avianca airline as their carrier provider (59.1\%), followed by a low-cost carrier (17.3\%). About $52.4 \%$ of the respondents had traveled for pleasure, while $38 \%$ of passengers had traveled for business.

Figure 3 shows the airline segmentations as a diverging stacked bar chart. Figure 3 summarizes the percentage of airlines assessed by respondents, according to the leading domestic routes. Most routes are dominated by Avianca airline, followed by Latam and Viva Air.

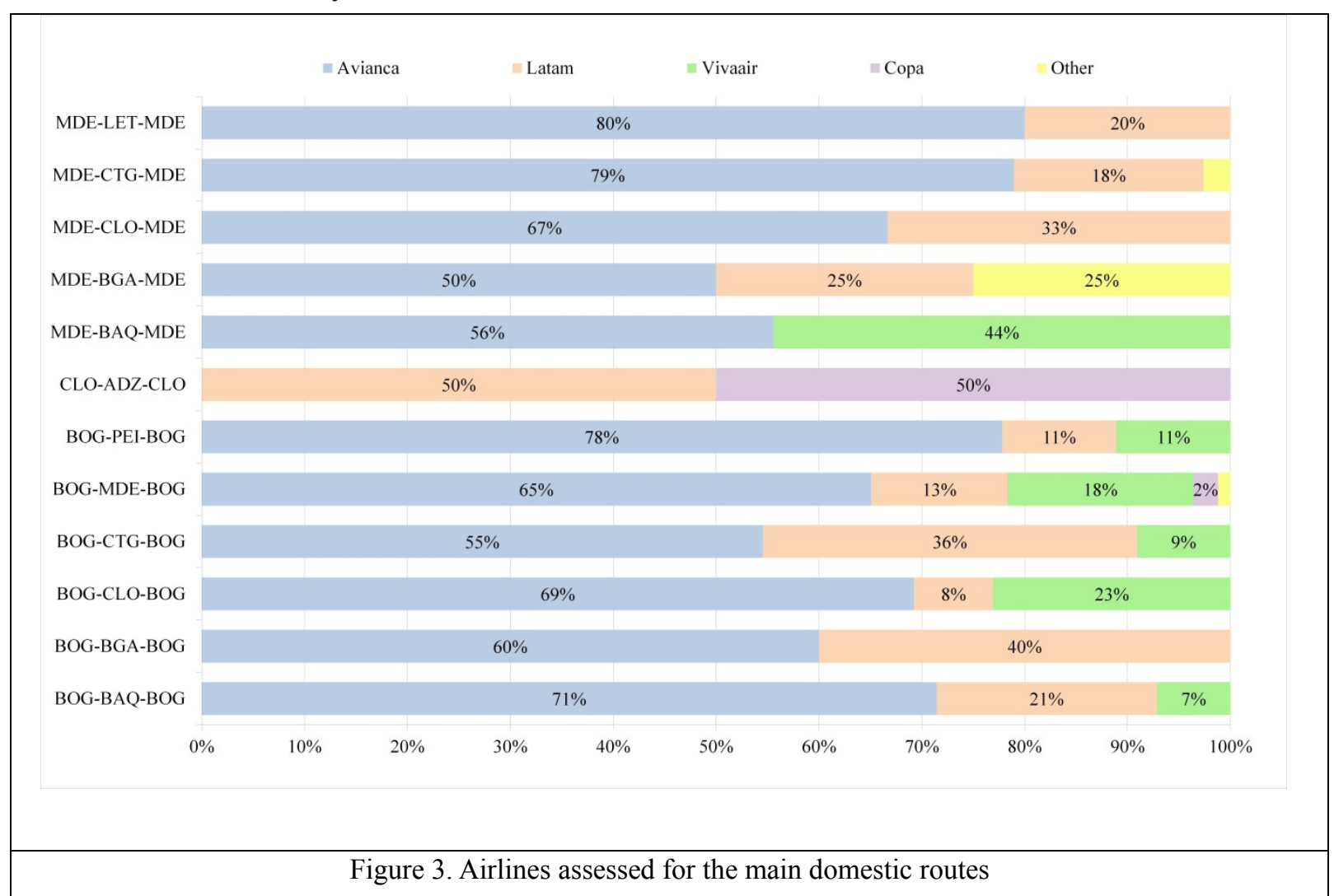

\subsection{Data Analysis}

In the first stage, the data was cleaned up through the detection of outliers. A well-known multivariate outlier detection statistical methodology based on Mahalanobis distance was used. The outlier detection was carried out by only considering the quantitative variables (age, number of suitcases, number of accompanying persons, airfare, and travel time). Implementing this methodology, 18 outliers were found during the analysis, by using the MATLAB (computer program) 2014 version. Second, the Statistical Package for Social Science (SPSS) computer program version 24 was used for the Exploratory Factor Analysis (EFA) and reliability test. Third, the measurement model was tested before trialing the structural model, by following the procedure suggested by Anderson \& Gerbing (1988). The Analysis of Moment Structure (AMOS) (computer program) 21 version (Byrne, 2010) was used for Confirmatory Factor Analysis (CFA) and Structural Equation Modelling (SEM) in order to assess the proposed model fit and test the six hypotheses presented above. 


\section{Findings}

\subsection{Reliability and Validity}

EFA explores the data and provides information when there are a large number of factors. An EFA model for service quality and traveler's satisfaction was implemented, which that determined if the number of dimensions and the loading of measured items confirmed the proposed model. EFA was performed, by using principal component extraction with VARIMAX rotation. Thereby, six dimensions were identified and named from the basic attributes covered. Table 2 shows the results of the EFA for service quality and satisfaction. Traveler's experience was assessed with service offered during an air travel, by including departure airport, airline, and arrival airport service items. Based on the outcomes of the EFA, and by following instructions by Hair, Black, Babin \& Anderson (2014), the five items with factor loading less than 0.5 were excluded from the scale. The items were: quality of catering served on the plane (AIR3), availability of health personnel during the flights (EMP5), airline office locations (EMP6) and the airline has a useful frequent flyer program (SAT8). By using the method proposed by Hair et al. (2014), 20 percent of the items could be deleted because of low factor loading. Outputs shown in Table 2 indicate that there are 54 items related to five dimensions of service quality and traveler's satisfaction.

Table 2. Results of factor analysis and reliability

\begin{tabular}{|c|c|c|c|c|}
\hline $\begin{array}{l}\text { Scale } \\
\text { Items }\end{array}$ & Statements & $\begin{array}{c}\text { Factor } \\
\text { loadings }\end{array}$ & $\begin{array}{c}\text { Variance } \\
\text { explained (\%) }\end{array}$ & $\begin{array}{l}\text { Cronbach's } \\
\quad \text { alpha }\end{array}$ \\
\hline \multicolumn{2}{|r|}{ Factor 1: Arrival Airport Tangibles (ATT) } & & 17.24 & 0.964 \\
\hline AT1 & Cleanliness of the arrival airport toilets & 0.76 & & \\
\hline AT2 & Number of shops in arrival airport & 0.84 & & \\
\hline AT3 & $\begin{array}{c}\text { Availability of different transportation modes at } \\
\text { the airport exit }\end{array}$ & 0.82 & & \\
\hline AT4 & Size of the arrival airport & 0.88 & & \\
\hline AT5 & $\begin{array}{c}\text { Effective air-conditioned areas for smokers in the } \\
\text { arrival airport }\end{array}$ & 0.69 & & \\
\hline AT6 & Good signage in the arrival airport & 0.87 & & \\
\hline AT7 & Availability of trolleys in the arrival airport & 0.77 & & \\
\hline AT8 & $\begin{array}{c}\text { Reliability of the security control system in the } \\
\text { arrival airport }\end{array}$ & 0.80 & & \\
\hline AT9 & $\begin{array}{c}\text { Employees' uniforms are visually appealing in the } \\
\text { arrival airport }\end{array}$ & 0.79 & & \\
\hline AT10 & Comfort of the baggage claim area & 0.82 & & \\
\hline AT11 & $\begin{array}{c}\text { Availability of a wide newspaper selection in the } \\
\text { arrival airport }\end{array}$ & 0.65 & & \\
\hline AT12 & Arrival airport is clean & 0.82 & & \\
\hline AT13 & Arrival airport is modern looking & 0.87 & & \\
\hline AT14 & Quality of air conditioning in the arrival airport & 0.80 & & \\
\hline \multicolumn{2}{|c|}{ Factor 2. Departure Airport Tangibles (DTT) } & & 16.09 & 0.956 \\
\hline DT1 & Cleanliness of the departure airport toilets & 0.72 & & \\
\hline DT2 & Number of shops in the departure airport & 0.79 & & \\
\hline DT3 & Parking space availability in the departure airport & 0.74 & & \\
\hline DT4 & Size of the departure airport & 0.81 & & \\
\hline DT5 & $\begin{array}{c}\text { Effective air-conditioned areas for smokers in the } \\
\text { departure airport }\end{array}$ & 0.71 & & \\
\hline DT6 & Excellent signage in the departure airport & 0.82 & & \\
\hline DT7 & Availability of trolleys in the departure airport & 0.78 & & \\
\hline DT8 & $\begin{array}{c}\text { Reliability of the security control system in the } \\
\text { departure airport }\end{array}$ & 0.77 & & \\
\hline DT9 & $\begin{array}{c}\text { Employees' uniforms are visually appealing in the } \\
\text { departure airport }\end{array}$ & 0.75 & & \\
\hline
\end{tabular}




\begin{tabular}{|c|c|c|c|c|}
\hline $\begin{array}{l}\text { Scale } \\
\text { Items }\end{array}$ & Statements & $\begin{array}{l}\text { Factor } \\
\text { loadings }\end{array}$ & $\begin{array}{c}\text { Variance } \\
\text { explained (\%) }\end{array}$ & $\begin{array}{l}\text { Cronbach's } \\
\text { alpha }\end{array}$ \\
\hline DT10 & Comfort of waiting hall in the departure airport & 0.77 & & \\
\hline DT11 & $\begin{array}{c}\text { Availability of a wide newspaper selection in the } \\
\text { departure airport }\end{array}$ & 0.70 & & \\
\hline DT12 & Departure airport is clean & 0.80 & & \\
\hline DT13 & Departure airport is modern looking & 0.86 & & \\
\hline DT14 & Quality of air conditioning in the departure airport & 0.80 & & \\
\hline & Factor 3. Airline Staff (PER) & & 11.46 & 0.963 \\
\hline PER1 & Employees' overall attitude & 0.90 & & \\
\hline PER2 & $\begin{array}{l}\text { Whether airline personnel give exact answers to } \\
\text { my questions }\end{array}$ & 0.92 & & \\
\hline PER3 & $\begin{array}{c}\text { Employees' experience and education level are } \\
\text { adequate }\end{array}$ & 0.90 & & \\
\hline PER4 & $\begin{array}{c}\text { Employees are knowledgeable abouth answering } \\
\text { my questions }\end{array}$ & 0.92 & & \\
\hline PER5 & Empathy of the airline personnel & 0.90 & & \\
\hline PER6 & Awareness of airline personnel's duties & 0.90 & & \\
\hline PER7 & Error-free reservation and ticketing transactions & 0.79 & & \\
\hline PER8 & Whether personnel take care of everyone equally & 0.78 & & \\
\hline & Factor 5. Airline Tangibles (ATAN) & & 9.01 & 0.949 \\
\hline AIR1 & Aircraft is clean & 0.86 & & \\
\hline AIR2 & Aircraft is modern looking & 0.87 & & \\
\hline AIR4 & Cleanliness of the plane toilets & 0.85 & & \\
\hline AIR5 & Cleanliness of the plane seats & 0.89 & & \\
\hline AIR6 & Comfort of the plane seats & 0.84 & & \\
\hline AIR7 & Quality of air conditioning on the planes & 0.86 & & \\
\hline & Factor 4. Satisfaction (SAT) & & 8.97 & 0.936 \\
\hline SAT1 & $\begin{array}{c}\text { My satisfaction with the airline and airports in this } \\
\text { journey has increased }\end{array}$ & 0.76 & & \\
\hline SAT2 & $\begin{array}{l}\text { My impression of the airline and airports in this } \\
\text { journey has improved }\end{array}$ & 0.76 & & \\
\hline SAT3 & $\begin{array}{c}\text { Now, I have a more positive attitude toward the } \\
\text { airline company }\end{array}$ & 0.78 & & \\
\hline SAT4 & Availability of low-price ticket offerings & 0.70 & & \\
\hline SAT5 & Consistency of ticket prices with given service & 0.78 & & \\
\hline SAT6 & Image of airline company & 0.68 & & \\
\hline SAT7 & The paid fare is acceptable & 0.75 & & \\
\hline & Factor 6. Airline Empathy (EMP) & & 6.29 & 0.847 \\
\hline EMP1 & On-time flights & 0.64 & & \\
\hline EMP2 & Transportation between city and airport & 0.79 & & \\
\hline EMP3 & Compensation schemes in case of loss or accident & 0.77 & & \\
\hline EMP4 & Care paid to passengers' luggage & 0.61 & & \\
\hline EMP7 & Number of flights to satisfy passengers' demand & 0.76 & & \\
\hline
\end{tabular}

Cronbach's alpha was used to assess reliability. Table 2 also shows the internal consistency of all the dimensions ranging from 0.847 (Airline Empathy) to 0.964 (Arrival Airport Tangibles). Values above 0.80 generally indicate a good reliability level (Hair et al., 2014). The Kaiser-Meyer-Olkin (KMO) measure was 0.93 . It confirms the adequacy of sampling for each variable in the model. The sample size is considered to be suitable for factor analysis because it is greater than 0.9 (Kaiser, 1974). 
Furthermore, the assumption of sphericity was rejected by the Bartlett test whose p-value was $p<0.0001$. Therefore, not all the coefficients are at zero and the variables considered in the survey are not uncorrelated so that the second requirement of factor analysis is satisfied. As a consequence, both conditions for carrying out the factor analysis were satisfied. Therefore, it was implemented.

The six factors explain $69.06 \%$ of the total variance. Factor 1 (Arrival Airport Tangibles) accounts for $17.24 \%$ of the total variance. Factor 2 (Departure Airport Tangibles) explains $16.09 \%$ of the total variance. Factor 3 (Airline Staff) accounts for $11.46 \%$ of the total variance. Factor 4 (Airline Tangibles) explains $9.01 \%$ of the total variance. Factor 5 (Satisfaction) accounts for $8.97 \%$ of the total variance. Finally, factor 6 (Airline Empathy) explains $6.29 \%$ of the total variance.

\subsection{Measurement Model}

The traveler's satisfaction model in air transportation was assessed, by using the SEM with latent variables by AMOS. The aim of constructing an SEM was to test whether the five dimensions of air transportation service quality have a significant influence on traveler's satisfaction. Besides, the supposition of whether traveler's satisfaction leads to traveler's loyalty was assessed. Based on literature review, traveler's loyalty was measured with four items (RI1: I consider this airline company my first option in this journey, WOW1: I say positive things about this airline and airports to other people, WOW2: I would recommend this airline and airports to someone, who seeks my advice and WOW3: I encourage my relatives and friends to fly with this airline between these airports). They are related to the repurchase intention (RI) and word-of-mouth (WOM).

The present research was based on the conceptual framework shown in Figure 4. The conceptual framework for that passenger satisfaction model has seven constructs: Airline tangibles (ATAN), airline staff (PER), airline empathy (EMP), departure airport tangibles (DTT), arrival airport tangibles (DTT), traveler's satisfaction (SAT), and traveler loyalty (LOY).

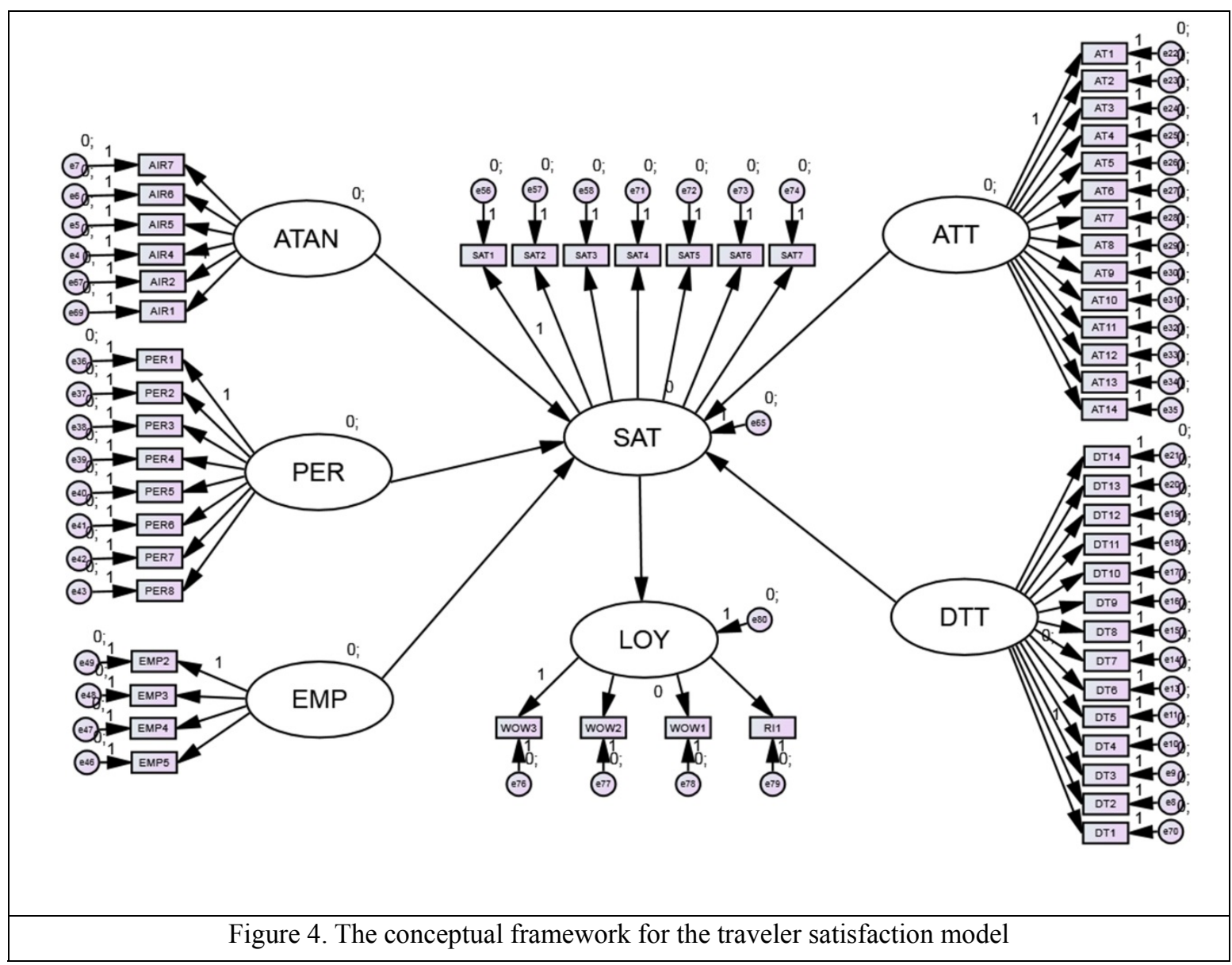

The CFA was performed to confirm the measurement model and to assess the degree to which the measured variables represent the number of constructs. By using a maximum likelihood estimation method, 58 items were subjected to a CFA with a seven-factor measurement model. The results of the CFA in Table 3 show that composite reliability (CR) ranged from 0.85 to 0.97 . These values were all greater than the recommended 
threshold of 0.70 suggested by Hair et al. (2014), implying that multiple items for each factor are internally consistent and reliable.

The average variance extracted (AVE) was used to assess convergent validity. AVE ranged from 0.53 to 0.82 , exceeding the recommended threshold value of 0.5 (Hair et al.,2014), which means that more than one-half of the variances observed in the items were explained by their hypothesized constructs. Therefore, the data has good convergent validity.

Table 3. Confirmatory factor analysis results

\begin{tabular}{ccc}
\hline Constructs & $\boldsymbol{C R}$ & $\boldsymbol{A V \boldsymbol { E }}$ \\
\hline ATT & 0.96 & 0.66 \\
DTT & 0.96 & 0.61 \\
PER & 0.97 & 0.78 \\
ATAN & 0.95 & 0.76 \\
EMP & 0.85 & 0.53 \\
SAT & 0.92 & 0.62 \\
LOY & 0.95 & 0.82 \\
\hline Goodness-of-fit: $\chi^{2} / d f=2.7, C F I=0.9$, RMSEA $=0.075$
\end{tabular}

By following the recommendations of Byrne, (2010) and Hair et al. (2014), the model was assessed based on the chi-square test, the comparative fit index (CFI), and the root square of approximation (RMSEA). The results of the model in Figure 4 indicated that the normed chi-square value $\left(\chi^{2} / d f\right)$ of the model was 2.7, which is below the threshold of 5.0. Also, the CFI has an acceptable value, which satisfies the recommended criteria for the cut-off of 0.9 (Hair et al., 2014). Another important index of model fit is the RMSEA value of 0.075 , which was smaller than 0.08 , by indicating an excellent model fit. Therefore, the hypothesized model had a good fit and was acceptable.

\subsection{Structural Model and Test of Hypotheses}

Firstly, a correlation analysis was performed on all of the constructs in order to assess the relationship between variables. Scores for each measure were obtained by averaging scores across items, which represent that construct. The complete results of the Pearson correlation analysis are presented in Table 4. All correlations found among the research constructs are significant at a level of 0.01 . The correlation among variables ranges from 0.120 (Departure airport tangibles and airline staff) to 0.779 (Satisfaction and loyalty). Significant positive relationships can be observed among airline tangibles, airline staff, airline empathy, departure airport tangibles, arrival airport tangibles, and traveler's satisfaction level. Additionally, a higher satisfaction level is associated with higher passenger loyalty.

Table 4. Descriptive statistics and correlation matrix

\begin{tabular}{cccccccc}
\hline & $A T T$ & $D T T$ & PER & ATAN & EMP & SAT & LOY \\
\hline ATT & 1 & & & & & & \\
DTT & $0.275^{*}$ & 1 & & & & & \\
PER & $0.246^{*}$ & $0.120^{*}$ & 1 & & & & \\
ATAN & $0.208^{*}$ & $0.320^{*}$ & $0.218^{*}$ & 1 & & & \\
EMP & $0.360^{*}$ & $0.319^{*}$ & $0.175^{*}$ & $0.149^{*}$ & 1 & & \\
SAT & $0.476^{*}$ & $0.457^{*}$ & $0.318^{*}$ & $0.311^{*}$ & $0.524^{*}$ & 1 & \\
LOY & $0.363^{*}$ & $0.309^{*}$ & $0.303^{*}$ & $0.302^{*}$ & $0.415^{*}$ & $0.779^{*}$ & 1 \\
Descriptive statistics & & & & & & & \\
Mean & 4.821 & 4.915 & 5.515 & 5.675 & 3.785 & 4.985 & 4.998 \\
Standard deviation & 1.449 & 1.335 & 1.370 & 1.275 & 1.606 & 1.492 & 1.570 \\
\hline
\end{tabular}

* Correlation is significant at 0.01 level.

A detailed examination of Table 5 shows that $\operatorname{ATAN}(\beta=0.127$; $\mathrm{t}$-value $=2.581 ; \mathrm{p}<0.05)$ have a significant positive 
effect on traveler's satisfaction. Thus, hypothesis H1 is supported. Table 5 also reveals that PER $(\beta=0.166$; $\mathrm{t}$-value $=3.427 ; \mathrm{p}<0.001$ ) have a significant effect on traveler's satisfaction, which means that $\mathrm{H} 2$ is supported. Similarly, the findings of this study also support H3, which proposes the significant influence of EMP $(\beta=0.480$; $\mathrm{t}$-value $=8.455 ; \mathrm{p}<0.001)$ on traveler's satisfaction. Furthermore, a high perception of service quality related to DTT has a significant positive effect on traveler's satisfaction $(\beta=0.203 ; \mathrm{t}$-value $=4.088 ; \mathrm{p}<0.001)$, supporting hypothesis H4. It can also be noted that the ATT has a significant relationship with traveler satisfaction $(\beta=0.237$; $\mathrm{t}$-value $=4.818 ; \mathrm{p}<0.001)$. Lastly, H6 hypothesized that there is a relationship between satisfaction and traveler loyalty. The results shown in Table 5 support this hypothesis $(\beta=0.786 ; \mathrm{t}$-value $=17.89 ; \mathrm{p}<0.001)$.

Table 5. Standardized estimates of the air travel experience model

\begin{tabular}{ccccccc}
\hline Hypothesis & $\begin{array}{c}\text { Endogenous } \\
\text { variable }\end{array}$ & & $\begin{array}{c}\text { Exogenous } \\
\text { variable }\end{array}$ & $\begin{array}{c}\text { Standardized } \\
\text { estimate }\end{array}$ & $t$-value & Result \\
\hline $\mathrm{H} 1$ & $\mathrm{SAT}$ & $\leftarrow$ & ATAN & 0.127 & $2.581^{* *}$ & Supported \\
$\mathrm{H} 2$ & $\mathrm{SAT}$ & $\leftarrow$ & PER & 0.166 & $3.427^{*}$ & Supported \\
$\mathrm{H} 3$ & $\mathrm{SAT}$ & $\leftarrow$ & EMP & 0.480 & $8.455^{*}$ & Supported \\
$\mathrm{H} 4$ & $\mathrm{SAT}$ & $\leftarrow$ & DTT & 0.203 & $4.088^{*}$ & Supported \\
$\mathrm{H} 5$ & $\mathrm{SAT}$ & $\leftarrow$ & ATT & 0.237 & $4.818^{*}$ & Supported \\
$\mathrm{H} 6$ & $\mathrm{LOY}$ & $\leftarrow$ & SAT & 0.786 & $17.890^{*}$ & Supported \\
\hline Notes: ${ }^{*} p<0.001 ; * * p<0.05$ & & & & &
\end{tabular}

\section{Discussion}

This study offers significant theoretical contributions. From a broader theoretical viewpoint, this study contributes to an understanding of the role of airline and airport service quality in air traveler experience. This paper contributes to airport and airline marketing strategy, by identifying the key role of departure airport service, airline service and arrival airport service in traveler's satisfaction. Besides, the research provides an original contribution to service quality literature. No studies have explored the role of arrival airport service quality as a stage of integral service.

This paper has presented a relationship model, which airline service quality, airline staff, airline empathy, service quality of departure airport, service quality of arrival airport, traveler's satisfaction, and traveler's loyalty as it pertains to domestic flights. From the evidence in Colombia, the results of the analysis provide important insights for airline and airport managers about the design of marketing strategies in order to manage their services better.

Empirical outputs via SEM demonstrated that service quality perception is a multidimensional construct, which includes service quality of departure airport, airline service quality, and service quality of arrival airport. The present study developed a new measurement scale called ATSQ. The scale developed here is both reliable and valid. Therefore, this study contributes to the literature on air traveler's experience assessment through the validation of the ATSQ instrument. This research extends on the current air traveler's experience literature to examine the effect of service quality on traveler's satisfaction and, in turn, the relationship between traveler's satisfaction and traveler's behavioral intention.

The service quality dimensions identified in this research diverge from SERVQUAL (Parasuraman et al., 1988), SERVPERF (Cronin and Taylor, 1992) and AIRQUAL (Ekiz et al., 2006), since ATSQ has a more detailed set of dimensions. ATSQ allows a better understanding of air travel experience.

All the hypotheses formulated in this study were tested. One of the main results is that traveler's satisfaction is affected by service quality dimensions, here called airline tangibles, airline staff, airline empathy, departure airport tangibles, and arrival airport tangibles. The results of this paper indicate that departure airport tangibles, arrival airport tangibles, and airline empathy factors are the most influential constructs in terms of traveler's satisfaction. In this regard, this research finding coincides with previous studies (Nadiri et al., 2008; Mohamed and Rani, 2016; Farooq et al., 2018) due to fact that the departure airport tangibles significantly affect traveler's satisfaction. Contrastingly, these results contradict a study developed in the Malaysian airline market by Suki (2014), where it is stated that airport tangibles do not have an impact on traveler's satisfaction. 


\section{Conclusion}

The fast growth of passenger traffic worldwide has influenced airlines and airports of the implementation of new management practices focused on air traveler's experiences. Therefore, service quality must be based on their perception of service attributes to understand the traveler's needs. Thus, more energy is being directed toward studying the nature of traveler's experience. This research extended the understanding of traveler's experience by exploring the elements, which influence traveler's satisfaction from a new perspective: that of the service quality perception related to all contact points that travelers experiences (departure airport, airline and arrival airport) during a travel.

The present research examined traveler's behavior in domestic flights, by constructing a comprehensive model, by incorporating several unique constructs. The model differs from previous studies, by considering the service quality of the arrival airport. The model suggests that the service quality of the arrival airport is a relevant aspect of traveler's satisfaction. This study was inspired by the open problems suggested by Bezerra \& Gomes (2015), who conjecture that airlines and airports services share a significant area of overlap.

This research validates the multidimensionality of ATSQ instrument and acknowledges attributes associated with airline, departure airport, and arrival airport. The study findings serve as a foundation to develop strategies in order to improve service quality in all its stages. On the one hand, outputs of this study can help airport authorities in order to drive loyalty, by continuously assessing the service standards. The best way to encourage passengers to re-use the airport is to upgrade airport facilities, comfort in waiting hall, and baggage claim area. On the other hand, this research provides direction for managers who need to use service quality as a critical element of their airline's competitive strategy. Service quality improvements influence not only travelers' perceptions, but also the overall attractiveness of the airline related to its competitors. Therefore, by allocating resources to the airline service quality elements such as airline facilities, flight-in service, employees knowledge, among other important aspects, can increase the likelihood of the airline will be perceived as the best choice, related to the alternatives available.

The present study also supports previous empirical findings, where the traveler's satisfaction is an important prerequisite of traveler's loyalty (Gures et al., 2014; Hussain et al., 2014; Leong et al., 2015; Kos Koklic et al., 2017). Therefore, this study contributes to traveler's loyalty literature due to the fact that loyalty is characterized by repurchase intention and word-of-mouth communications. Hence, airline and airport management should try to keep service quality at a high level in order to increase traveler's satisfaction.

\section{References}

Abdullah, K., Jan, M., Hazilah, N. \& Manaf, A. (2012). A structural equation modelling approach to validate the dimensions of servperf in airline industry of Malaysia. International Journal of Engineering and Management Sciences, 3(2), 134-141.

Aburoub, A., Hersh, A. \& Aladwan, K. (2011). Relationship between Internal Marketing and Service Quality with Customers' Satisfaction. International Journal of Marketing Studies, 3(2), 107-118. https://doi.org/10.5539/ijms.v3n2p107

Aerocivil. (2019). Estadisticas trafico de aeropuertos 2018.

Aksoy, S., Atilgan, E. \& Akinci, S. (2003). Airline services marketing by domestic and foreign firms: Differences from the customers' viewpoint. Journal of Air Transport Management, 9(6), 343-351. https://doi.org/10.1016/S0969-6997(03)00034-6

Al-Refaie, A., Bata, N., Eteiwi, D. \& Jalham, I. (2014). Examining factors that affect passenger's overall satisfaction and loyalty: Evidence from Jordan airport. Jordan Journal of Mechanical and Industrial Engineering, 8(2), 94-101.

Ali, F., Lal Dey, B. \& Filieri, R. (2015). An assessment of service quality and resulting customer satisfaction in Pakistan International Airlines: Findings from foreigners and overseas Pakistani customers. International Journal of Quality and Reliability Management, 32(5), 486-502. https://doi.org/10.1108/EL-01-2014-0022

An, M. \& Noh, Y. (2009). Airline customer satisfaction and loyalty: Impact of in-flight service quality. Service Business, 3(3), 293-307. https://doi.org/10.1007/s11628-009-0068-4

Anderson, J. C. \& Gerbing, D. W. (1988). Structural equation modeling in practice: A review and recommended two-step approach. Psychological Bulletin, 103(3), 411-423. https://doi.org/10.1037/0033-2909.103.3.411

Babbar, S. \& Koufteros, X. (2008). The human element in airline service quality: contact personnel and the customer. International Journal of Operations \& Production Management, 28(9), 804-830. 
https://doi.org/10.1108/01443570810895267

Bezerra, G. C. L. \& Gomes, C. F. (2015). The effects of service quality dimensions and passenger characteristics on passenger's overall satisfaction with an airport. Journal of Air Transport Management, 44-45, 77-81. https://doi.org/10.1016/j.jairtraman.2015.03.001

Bogicevic, V., Yang, W., Bilgihan, A. \& Bujisic, M. (2013). Airport service quality drivers of passenger satisfaction. Tourism Review, 68(4), 3-18. https://doi.org/10.1108/TR-09-2013-0047

Byrne, B. M. (2010). Structural equation modeling with AMOS: Basic concepts, applications, and programming. Routledge, 22, https://doi.org/10.4324/9781410600219

Chen, C. F. (2008). Investigating structural relationships between service quality, perceived value, satisfaction, and behavioral intentions for air passengers: Evidence from Taiwan. Transportation Research Part A: Policy and Practice, 42, 709-717. https://doi.org/10.1016/j.tra.2008.01.007

Chen, L., Li, Y. Q. \& Liu, C. H. (2019). How airline service quality determines the quantity of repurchase intention - Mediate and moderate effects of brand quality and perceived value. Journal of Air Transport Management, 75(November 2018), 185-197. https://doi.org/10.1016/j.jairtraman.2018.11.002

Cronin, J. J. \& Taylor, S. A. (1992). Measuring Service Quality: A Reexamination and Extension. Journal of Marketing, 56(3), 55-68. Retrieved from http://www.jstor.org/stable/1252296

Cronin, J. J. \& Taylor, S. A. (1994). SERVPERF versus SERVQUAL: reconciling performance-based and perceptions-minus-expectations measurement of service quality. Journal of Marketing, 58(January 1994), 125-132. https://doi.org/10.2307/1252256

Cunningham, L. F., Young, C. E. \& Lee, M. (2004). Perceptions of Airline Service Quality: Pre and Post 9/11. Public Works Management \& Policy, 9(1), 10-25. https://doi.org/10.1177/1087724X04265135

David Mc. A, B. (2013). Service Quality and Customer Satisfaction in the Airline Industry: A Comparison between Legacy Airlines and Low-Cost Airlines. American Journal of Tourism Research, 2(1), 67-77. https://doi.org/10.11634/216837861302317

Díaz, O. \& Pulido, L. (2019). Measurement of Airport Efficiency. The Case of Colombia. Transport and Telecommunication Journal, 20(1), 40-51. https://doi.org/10.2478/ttj-2019-0004

Eboli, L. \& Mazzulla, G. (2009). An ordinal logistic regression model for analysing airport passenger satisfaction. EuroMed Journal of Business, 4(1), 40-57. https://doi.org/10.1108/14502190910956684

Ekiz, H. E., Hussain, K. \& Bavik, A. (2006). Perceptions of service quality in North Cyprus Airline. Tourism and Hospitality Industry 2006 - New Tends in Tourism and Hospitality Management, Proceedings of 18th Biennial International Conference, Faculty of Tourism and Hospitality Management, Opatija, 03-05, 778-790.

Elkhani, N., Soltani, S. \& Jamshidi, M. H. M. (2014). Examining a hybrid model for e-satisfaction and e-loyalty to e-ticketing on airline websites. Journal of Air Transport Management, 37, 36-44. https://doi.org/10.1016/j.jairtraman.2014.01.006

Farooq, M., Shoaib, A., Salam, M., Fayolle, A., Jaafar, N. \& Ayupp, K. (2018). Impact of service quality on customer satisfaction in Malaysia airlines: A PLS-SEM approach. Journal of Air Transport Management, 67(September 2017), 169-180. https://doi.org/10.1016/j.jairtraman.2017.12.008

Fodness, D. \& Murray, B. (2007). Passengers' expectations of airport service quality. Journal of Services Marketing, 21(7), 492-506. https://doi.org/10.1108/08876040710824852

George, B. P., Henthorne, T. L. \& Panko, T. R. (2013). ASQual: measuring tourist perceived service quality in an airport setting. International Journal of Business Excellence, 6(5), 526-536. https://doi.org/10.1504/ijbex.2013.056093

Gures, N., Arslan, S. \& Yucel Tun, S. (2014). Customer Expectation, Satisfaction and Loyalty Relationship in Turkish Airline Industry. International Journal of Marketing Studies, 6(1), 66-74. https://doi.org/10.5539/ijms.v6n1p66

Gursoy, D., Chen, M. H. \& Kim, H. J. (2005). The US airlines relative positioning based on attributes of service quality. Tourism Management, 26(1), 57-67. https://doi.org/10.1016/j.tourman.2003.08.019

Hair, J., Black, W., Babin, B. \& Anderson, R. (1999). Multivariate Data Analysis. (E. C. P. Hall, Ed.) (5ta ed.).

Huang, Y.-K. (2009). The Effect of Airline Service Quality on Passengers' Behavioural Intentions Using 
SERVQUAL Scores: A TAIWAN Case Study. Journal of the Eastern Asia Society for Transportation Studies, $\quad$ 8(1), 2330-2343. $\quad$ Retrieved from https://pdfs.semanticscholar.org/cede/5829392008ed89cfc182ae47091e6ea6c131.pdf

Hussain, R., Al Nasser, A. \& Hussain, Y. K. (2014). Service quality and customer satisfaction of a UAE-based airline: An empirical investigation. Journal of Air Transport Management, 42, 167-175. https://doi.org/10.1016/j.jairtraman.2014.10.001

Jeon, S. \& Kim, M.-S. (2012). The effect of the servicescape on customers' behavioral intentions in an international airport service environment. Service Business, 6(3), 279-295. https://doi.org/10.1007/s11628-012-0136-z

Kaiser, H. F. (1974). An index of factorial simplicity. Psychometrika, 39(1), 31-36. https://doi.org/10.1007/BF02291575

Khuong, M. N. \& Uyen, L. T. M. (2014). The Factors Affecting Vietnam Airlines Service Quality and Passenger Satisfaction - A Mediation Analysis of Service Quality. International Journal of Innovation, Management and Technology, 5(5), 327-333. https://doi.org/10.7763/IJIMT.2014.V5.535

Kim, Y. K. \& Lee, H. R. (2011). Customer satisfaction using low cost carriers. Tourism Management, 32(2), 235-243. https://doi.org/10.1016/j.tourman.2009.12.008

Kirk, P. J., Harrison, A., Popovic, V. \& Kraal, B. (2014). Deconstructing Expected Passenger Experience in Airports. In DRS2014 International Conference of the Design Research Society Proceedings. Umea, Sweden.

Kos Koklic, M., Kukar-Kinney, M. \& Vegelj, S. (2017). An investigation of customer satisfaction with low-cost and full-service airline companies. Journal of Business Research, 80(May), 188-196. https://doi.org/10.1016/j.jbusres.2017.05.015

Kuljanin, J., Paskota, M. \& Kalić, M. (2018). Methodological framework for the investigation on the rapidly growing air travel market - An application of multivariate statistical analysis. Journal of Air Transport Management, 72(February), 86-91. https://doi.org/10.1016/j.jairtraman.2018.02.003

Lee, K. \& Yu, C. (2018). Assessment of airport service quality: A complementary approach to measure perceived service quality based on Google reviews. Journal of Air Transport Management, 71(May), 28-44. https://doi.org/10.1016/j.jairtraman.2018.05.004

Leong, L. Y., Hew, T. S., Lee, V. H. \& Ooi, K. B. (2015). An SEM-artificial-neural-network analysis of the relationships between SERVPERF, customer satisfaction and loyalty among low-cost and full-service airline. Expert Systems with Applications, 42(19), 6620-6634. https://doi.org/10.1016/j.eswa.2015.04.043

Mahmud, A., Jusoff, K. \& Hadijah, S. T. (2013). The effect of service quality and price on satisfaction and Loyalty of Customer of commercial flight service industry. World Applied Sciences Journal, 23(3), 354-359. https://doi.org/10.5829/idosi.wasj.2013.23.03.13052

Ming-kei, C. \& Yui-Yip, L. (2016). Travelers' Perception on Airport Satisfaction. Journal of Business \& Economic Policy, 3(2), 55-60.

Mohamed, M. S. \& Rani, S. A. (2016). Modeling customer satisfaction using structural equation modeling based on service quality measurement in airline. International Journal of Management, 7(6), 6-14. Retrieved from http://www.iaeme.com/IJM/issues.asp?JType=IJM\&VType=7\&IType=6

Nadiri, H., Hussain, K., Ekiz, E. H. \& Erdogan, S. (2008). An investigation on the factors influencing passengers' loyalty in the North Cyprus national airline. The TQM Journal, 20(3), 265-280. https://doi.org/10.1108/17542730810867272

Namukasa, J. (2014). The influence of airline service quality on passenger satisfaction and loyalty: The case of Uganda airline industry. The TQM Journal, 25(5), 520-532. https://doi.org/10.1108/TQM-11-2012-0092

Parasuraman, A., Zeithaml, V. A. \& Berry, L. L. (1988). SERVQUAL: A Multiple-Item scale for Measuring Consumer Perceptions of Service Quality. Journal of Retailing, https://doi.org/10.1016/S0148-2963(99)00084-3

Park, E. (2019). The role of satisfaction on customer reuse to airline services: An application of Big Data approaches. Journal of Retailing and Consumer Services, 47(November 2018), 370-374. https://doi.org/10.1016/j.jretconser.2019.01.004 
Park, J.-W., Robertson, R. \& Wu, C.-L. (2005). Investigating the Effects of Service Quality on Airline Image and Behavioural Intentions: Findings from Australian International Air Passengers. Journal of Tourism Studies, 16(1), 2-11.

Park, J.-W., Robertson, R. \& Wu, C.-L. (2006). Modelling the Impact of Airline Service Quality and Marketing Variables on Passengers' Future Behavioural Intentions. Transportation Planning and Technology, 29, 359-381. https://doi.org/10.1080/03081060600917686

Park, J. W. (2010). The effect of frequent flyer programs: A case study of the Korean airline industry. Journal of Air Transport Management, 16(5), 287-288. https://doi.org/10.1016/j.jairtraman.2010.02.007

Prentice, C. \& Kadan, M. (2019). The role of airport service quality in airport and destination choice. Journal of Retailing and Consumer Services, 47(November 2018), 40-48. https://doi.org/10.1016/j.jretconser.2018.10.006

Saadat, M., Tahbet, T. R. \& Mannan, M. A. (2018). Factors That Influence Customer Satisfaction in Airline Industry in Malaysia. IOSR Journal of Business and Management (IOSR-JBM), 20(8), 1-6. https://doi.org/10.9790/487X-2008050106

Shoaib, M., Salam, M., Fayolle, A. \& Jaafar, N. (2018). Impact of service quality on customer satisfaction in Malaysia airlines: A PLS-SEM approach. Journal of Air Transport Management, 67, 169-180. https://doi.org/10.1016/j.jairtraman.2017.12.008

Suki, N. M. (2014). Passenger satisfaction with airline service quality in Malaysia: A structural equation modeling approach. Research in Transportation Business and Management, 10, $26-32$. https://doi.org/10.1016/j.rtbm.2014.04.001

\section{Copyrights}

Copyright for this article is retained by the author(s), with first publication rights granted to the journal.

This is an open-access article distributed under the terms and conditions of the Creative Commons Attribution license (http://creativecommons.org/licenses/by/4.0/). 